\title{
The quiensabe, Hedeoma piperita (Lamiaceae), a species with cultural importance in the indigenous community of San Francisco Pichátaro, Michoacán, Mexico: bases for its conservation management
}

\section{Acta Botanica Mexicana}

\section{El quiensabe, Hedeoma piperita (Lamiaceae), una especie con importancia cultural en la comunidad indígena de San Francisco Pichátaro, Michoacán, México: bases para su manejo de conservación}

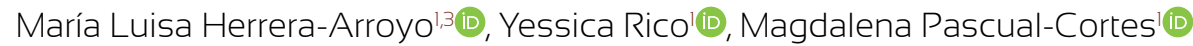

\begin{abstract}
Background and Aims: Hedeoma piperita is a plant popularly known as quiensabe and with traditional uses by the Purépecha people of San Francisco Pichátaro in Michoacán, Mexico. Despite its cultural relevance, the populations of $H$. piperita have been drastically reduced due to overexploitation. This work evaluated the traditional knowledge on the biology, ecology, and management of $H$. piperita among the indigenous community of San Francisco Pichátaro. Moreover, we aimed to evaluate its phenological development and relationships between phenological phases and local environmental variables.

Methods: We applied 75 semi-structured surveys among women and men in three age groups of the community. Phenological analyses were conducted for 31 plants established in the wild and by recording the height, total number of leaves, branches, flowers, fruits and sprouts every 15 days from March 2014 to March 2015. Significant correlations between phenological and environmental variables were calculated using Spearman's correlation coefficients.

Key results: Sixty percent of the interviewed people knew and have used $H$. piperita, and most of them were women (71\%). Alimentary purposes (as breakfast tea) were recognized as the main use among children and young people, while adults used it mostly for medicinal purposes. However, among the interviewees, little was known about the biological and ecological aspects of the species. We found that the stages of flowering and fructification overlap with the most intensive extraction season.

Conclusions: Urgent management strategies are needed to recover and maintain this species in the wild, and within the Purépecha cosmos-corpuspraxis complex.
\end{abstract}

Key words: local extinction, management, non-timber forest products, phenological phases, plant harvesting.

\section{Resumen}

Antecedentes y Objetivos: Hedeoma piperita es una especie popularmente conocida como quiensabe con importantes usos tradicionales entre los purépechas de San Francisco Pichátaro en Michoacán, México. A pesar de su importancia cultural, las poblaciones de $H$. piperita han sido reducidas drásticamente debido a la sobreexplotación. Este trabajo se realizó para evaluar el conocimiento tradicional acerca de la biología, ecología y manejo de H. piperita en la comunidad indígena de San Francisco Pichátaro. Además, se evaluó su desarrollo fenológico y las relaciones entre fases fenológicas y variables ambientales locales.

Métodos: Se realizaron 75 encuestas semiestructuradas en hombres y mujeres en tres grupos de edades de la comunidad. El análisis fenológico se realizó en 31 plantas en estado silvestre y se registró la altura, el número total de hojas, ramas, flores, frutos y retoños cada 15 días entre marzo de 2014 y marzo de 2015. Las correlaciones entre las variables fenológicas y ambientales se calcularon utilizando el coeficiente de correlación de Spearman. Resultados clave: Sesenta por ciento de los entrevistados reconocieron y han usado a $\mathrm{H}$. piperita, siendo la mayoría mujeres (71\%). Los usos alimenticios (té en el desayuno) fueron reconocidos como el principal uso por niños y jóvenes, mientras que los adultos la usan principalmente como medicinal. Sin embargo, entre los entrevistados muy pocos conocen detalles de la biología y ecología de la especie. Encontramos que las etapas de floración y fructificación coinciden con la temporada de recolección.

Conclusiones: Es urgente diseñar estrategias de manejo que permitan recuperar las poblaciones silvestres para seguir manteniendo a la especie dentro del complejo cosmos-corpus-praxis purépecha.

Palabra clave: cosecha de plantas, extinción local, fases fenológicas, manejo de recursos, productos forestales no maderables.

\footnotetext{
${ }^{1}$ Universidad Intercultural Indígena de Michoacán, Carretera Pátzcuaro-Huecorio, km 3 s/n, 61605 Pátzcuaro, Michoacán, México.

${ }^{2}$ Instituto de Ecología A.C., Centro Regional del Bajío, Red de Diversidad Biológica del Occidente Mexicano, Avenida Lázaro Cárdenas 253, 61600 Pátzcuaro, Michoacán, México. CONACyT, Avenida Insurgentes Sur 1582, 03940 México City, México

${ }^{3}$ Author for correspondence: luisa.herrera@uiim.edu.mx
}

Received: February 20, 2021.

Reviewed: April 5, 2021.

Accepted by Marie-Stéphanie Samain: May 21, 2021.

Published Online first: June 7, 2021.

Published: Acta Botanica Mexicana 128(2021).
To cite as: Herrera-Arroyo, M. L., Y. Rico and M. Pascual-Cortes. 2021. The quiensabe, Hedeoma piperita (Lamiaceae), a species with cultural importance in the indigenous community of San Francisco Pichátaro, Michoacán, Mexico: bases for its conservation management. Acta Botanica Mexicana 128: e1863. DOI: https://doi.org/10.21829/abm128.2021.1863

e-ISSN: $2448-7589$ 


\section{Introduction}

Indigenous people are repositories of abundant ecological knowledge, usually of a local, collective, diachronic and holistic nature. These human groups possess long histories of practice in using these resources that have led to the construction of cognitive systems related to the natural resources that surround them, and that are transmitted from generation to generation. Because transmitting this knowledge takes place through language, memory is the most important intellectual source among indigenous cultures (Alarcón-Chaires, 2009).

Ethnoecology is defined as an inter- and transdisciplinary field that explores how human cultural groups visualize nature through a framework of beliefs and knowledge, and how they exploit and/or manage their natural resources within those terms (Toledo, 1992; Toledo et al., 2002). Local ecological knowledge can be understood as a complex form of habitat adaptation and modification, and as the result of a coevolution process between culture and nature (Berkes et al., 2000). This discipline involves the interdisciplinary study of how people perceive nature through a specific cosmos corpus praxis complex; that is, the triple exploration of systems of beliefs (cosmos), the complete repertory of knowledge or cognitive systems (corpus), and the set of productive practices, including the different uses and management of natural resources (praxis), and how people use and manage those resources through their systems of symbolic beliefs and representations (Toledo, 2002). This field offers a holistic vision and a human or socioecological approach by applying various epistemologies and methodological procedures (Barrera-Bassols and Toledo, 2005).

The conceptual framework of ethnoecology allows analyzing the articulation of systems of beliefs, traditional knowledge and techniques of the handlers in the different expressions of forms of management (Blancas et al., 2016). Management can be defined as those practices and decisions made by humans in order to transform, recover or conserve elements, ecosystems or processes occurring in those systems, with the purpose of satisfying human needs, cultural purposes or general desires (Blancas et al., 2013). Many plant resources are managed according to their bio- logical and ecological characteristics (life cycle, type of reproductive system, distribution, abundance, among others) (Blancas et al., 2013; Casas et al., 2016). According to their importance for a human culture it is possible to expect that not all plants will be managed in the same way or the same intensity (González-Insuasti and Caballero, 2007).

Several authors have documented a close relationship between cultural and ecological diversity (Toledo et al., 2002; Reyes-García and Martín, 2007). Some ethnic and rural groups have developed suitable forms of exploiting and managing resources based on diverse techniques and practices for handling nature elements such as fire, water, and soil. These, in turn, are intimately related to the sustainability of traditional management practices and have led to the domestication of many resources utilized (Challenger, 1998; Boege, 2008).

Some studies have emphasized the role of local systems of ecological knowledge in the management and conservation of biological diversity (Laird, 2002; Perez-Negrón and Casas, 2007; Lira et al., 2009; Beltrán-Rodríguez et al., 2012). Other research has postulated that traditional societies are the main guardians of the preservation of areas and natural resources (Boege, 2008; Shiva, 2008; Toledo and Barrera-Bassols, 2008).

However, other realities also exist, one delimited by the economic conditions that indigenous and rural communities currently have, which result in negative impacts on wild populations of diverse species by the overexploitation of natural resources, thus disrupting ecological and demographic population dynamics (Ticktin, 2004). The overexploitation of many forest products affects the abundance of these resources and may lead to their local extirpation (Ticktin, 2004; López-Hoffman et al., 2006; Casas et al., 2009; Beltrán-Rodríguez et al., 2012) due to several key facts: 1) many species are gathered from natural populations, 2) their exploitation involves some degree of habitat modification, and 3) gathering reflects the demand that exists for the resource, regardless of its availability (Reyes-García et al., 2005; González-Insuasti and Caballero, 2007).

The search for new alternatives that favor the protection, conservation, and adequate use of natural resourc- 
es is evident, especially in regions that are under strong environmental, social and economic pressures. In this way, rural and indigenous communities will largely define the conservation of natural resources (Bocco et al., 2000).

In addition to ethnoecological studies in indigenous communities, phenological studies are essential to perform sustainable and management strategies in wild plants (Fiallo et al., 2000). Phenological studies allow to establish chronological records of the different phases of the growth and development of plants, including the seasonality of foliation, flowering, and fruit production during one annual cycle (Terborgh, 1992; Fiallo et al., 2000), and likely relationships with the environmental conditions that predominate in their habitat (Fenner, 1998).

Plant phenology information has been extremely valuable for management of biodiversity and ecological systems, contributing to the establishment of best practices in the management of natural resources (Enquist et al., 2014). Species-level phenology can contribute to natural resource management decisions, such as cultivation, harvesting, gathering, grazing, etc. (Browning et al., 2018). The use of phenological information has the potential to be an important tool for assessing the sensitivity, adaptive capacity, and overall vulnerability of species and ecosystems to timing changes (Enquist et al., 2014).

The Purépecha ethnic group was one of the major empires of the Pre Columbian era. Today they settle in the highlands of central Michoacán in Mexico, in the region known as the Purépecha Plateau (Argueta, 2008). The Purépechas have conserved ample traditional knowledge on the utilization of natural resources (plants, animals, and mushrooms) and have a tradition for optimizing the consumption of edible, medicinal, ornamental and firewood resources (Caballero, 1982; Caballero and Mapes, 1985; Argueta, 2008).

The plant locally known as quiensabe, Hedeoma piperita Benth., on the Purépecha Plateau, belongs to the Lamiaceae family. It is endemic to Mexico where it is distributed in pine-oak forests, pasturelands and secondary vegetation (Lara-Cabrera et al., 2016). This wild species has great cultural value and is widely used in several Purépecha towns; however, there is scarce documental information about its use.
Traditionally, H. piperita has been used as a medicinal plant prescribed by traditional healers (curanderos) as a remedy for gastrointestinal problems, colic, and the common cold, among other ailments (Caballero and Mapes, 1985; Herrera-Arroyo et al., 2020). In addition, it is commonly consumed as a tea in the daily diet of local families. Indeed, whole families often go to gather the plant, but frequently do so in great quantities that deplete local populations (Pascual, 2016).

No specific management practices have been referred to, and their populations are shrinking and becoming more infrequent (pers. obs). Unfortunately, there is no documentation on the ecology and biology of the species, and its cultivation has not been achieved (Pascual, 2016), so the study of the knowledge of the species, local practices, as well as its phenology, will allow the formulation of management strategies appropriate to the conditions of the Purépecha communities.

Our central goal is to contribute to the conservation of the quiensabe (Hedeoma piperita), for which it is necessary to: 1 ) evaluate the traditional knowledge on the biology, ecology and species management and its transmission among members of the indigenous community of San Francisco Pichátaro in Michoacán; 2) evaluate the phenological development of the species; and 3) determine the relationship between the phenological phases identified and environmental variables at their growing sites, in order to generate information that can be used for the development of conservation management strategies.

\section{Materials and Methods}

\section{Study site}

The indigenous community of San Francisco Pichátaro is of Purépecha origin. In 1596, seven indigenous towns, Hiracuaro, Chatar jatzicurin, Jurundikua, Domio, Ahuiran or Huiracaro, Charachapo and Arachurin, were congregated to form this town; today, these origins are preserved in the names of its neighborhoods (barrios). It was not until the arrival of the Franciscan friars that San Francisco Pichátaro received its name (PROCYMAF II, 2004). The town has an extent of 9088 ha and is located in the northeastern area of the Tingambato municipality, in the state of Michoacán in western Mexico. Its coordinates are $19^{\circ} 31^{\prime} 09^{\prime \prime}, 19^{\circ} 38^{\prime} 29^{\prime \prime} \mathrm{N}$ 
latitude and $101^{\circ} 45^{\prime} 53^{\prime \prime}, 101^{\circ} 52^{\prime} 20^{\prime \prime} \mathrm{W}$ longitude (Fig. 1). The surrounding region is called "Meseta Purépecha", which is surrounded by high mountains, including the Cerro de las Estacas (2900 m a.s.l.) to the northwest, the Cerro del Chivo (2800 $\mathrm{m}$ a.s.l.) to the north, the Cerro Ichatzucun (2640 m a.s.I.) to the west, the Cerro Huinumba (2620 m a.s.I.) to the southwest, and the Cerro de la Virgen (3200 m a.s.l.) to the south. Kananguio valley is located between the Cerro del Chivo, the Cerro de la Virgen and the Cerro de las Estacas (PROCYMAF II, 2004).

Climate is temperate sub-humid with rains in summer. The average annual precipitation is $1000 \mathrm{~mm}$ and the average annual temperature is $15^{\circ} \mathrm{C}$; however, both factors vary significantly according to elevation (BarreraBassols and Zinck, 2003). The predominant natural vegetation includes pine, pine-oak, and oak forests, with broad tracts of land devoted to rainfed agriculture and extensive cattle-raising (Toledo and Barrera-Bassols, 2008). The local economy is based primarily on forest resources, especially the intensive exploitation of wood for sale as timber and forest products and resources used to make furniture and handicrafts (Toledo and Barrera-Bassols, 2008). However, non-wood forest resources are also used as foods for domestic consumption and as potential sources of income (Felipe, 2015; Pascual, 2016).

San Francisco Pichátaro obtained ownership of communal assets by presidential decree in December 1953; residents are owners of natural resources (Suarez et al., 2000). The community has a population of 4952 inhabitants, of which 2366 are men and 2586 women, $16.4 \%$ speak the Purépecha language (Pascual, 2016). San Francisco Pichátaro is one of the communities that currently preserves several populations of $H$. piperita, as well as maintaining the tradition of its use (Herrera-Arroyo et al., 2020); however, H. piperita populations are becoming scarcer and less abundant.

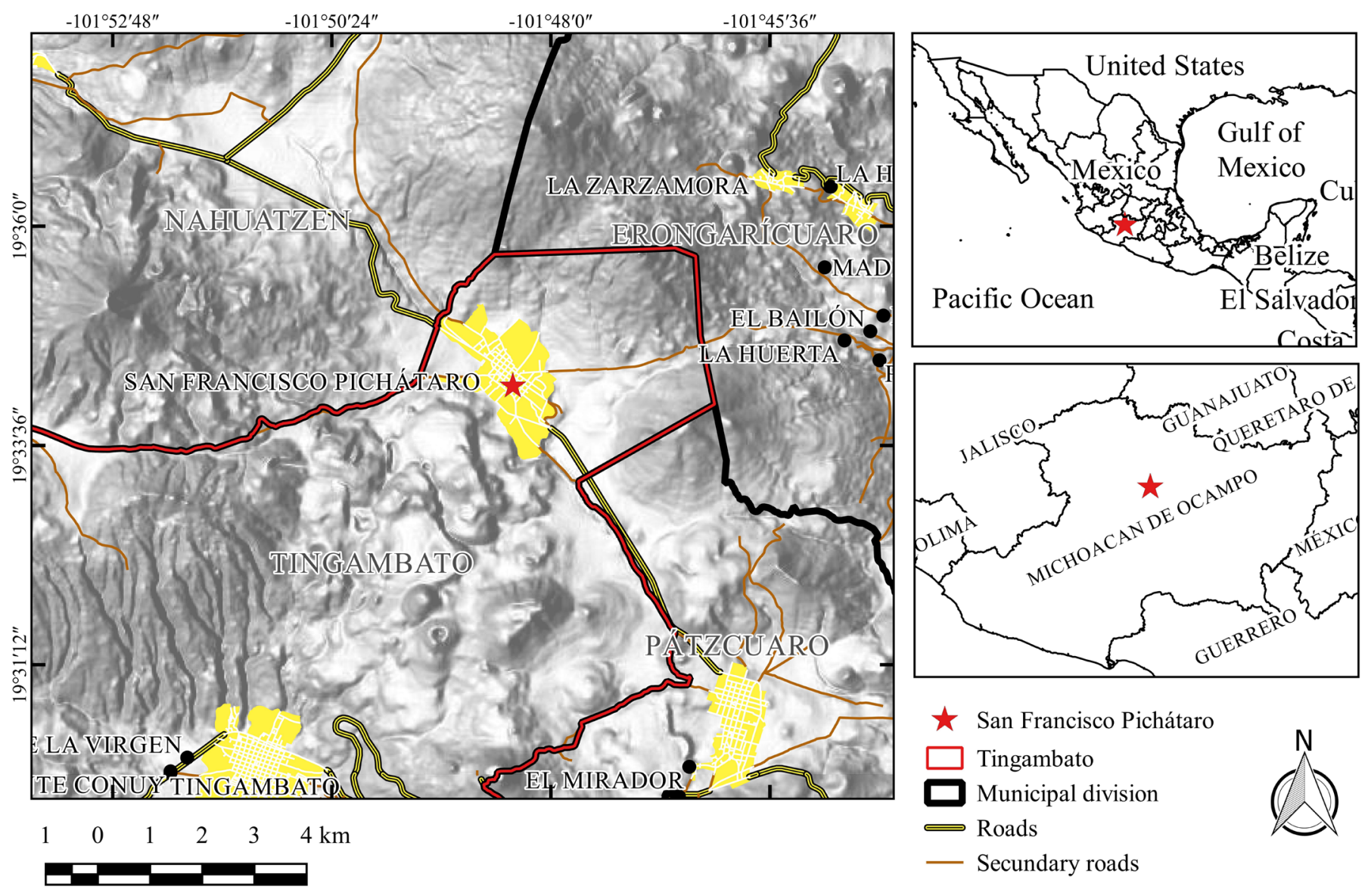

Figure 1: Geographical location of the indigenous community of San Francisco Pichátaro, Michoacán, Mexico. 


\section{Study species}

Hedeoma piperita is an endemic perennial herb that occurs in small racemes, scattered within pine-oak forests along the Trans-Mexican Volcanic Belt in Mexico (Martínez-Gordillo et al., 2013; Lara-Cabrera et al., 2016; Martínez-Gordillo et al., 2017). Hedeoma piperita was described in very simple morphological terms in 1835 by Bentham (18321836). Later, Irving (1980), based on herbarium specimens, carried out a more comprehensive taxonomic description of the genus and described the species in a more detailed way in "The Systematics of Hedeoma (Labiateae)".
Recently, Herrera-Arroyo et al. (2020) evaluated the morphological and genetic diversity and differentiation between populations from Michoacán. It is an aromatic, pubescent, herbaceous plant that grows to a height of 6-20.5 $\mathrm{cm}$. Its ovate-deltoid shaped leaves are dark green in color, 4-10.7 $\mathrm{mm}$ in width, and 6-12.3 $\mathrm{mm}$ in length. The flowers are white or purplish-white and form groups of a few flowers at the end of small branches. Its fruits are small, round and brown (Figs. 2, 3) (Herrera-Arroyo et al., 2020).

In the Purépecha region it is commonly known as quiensabe, hierba de Santo Domingo, Parash or Paracheña.
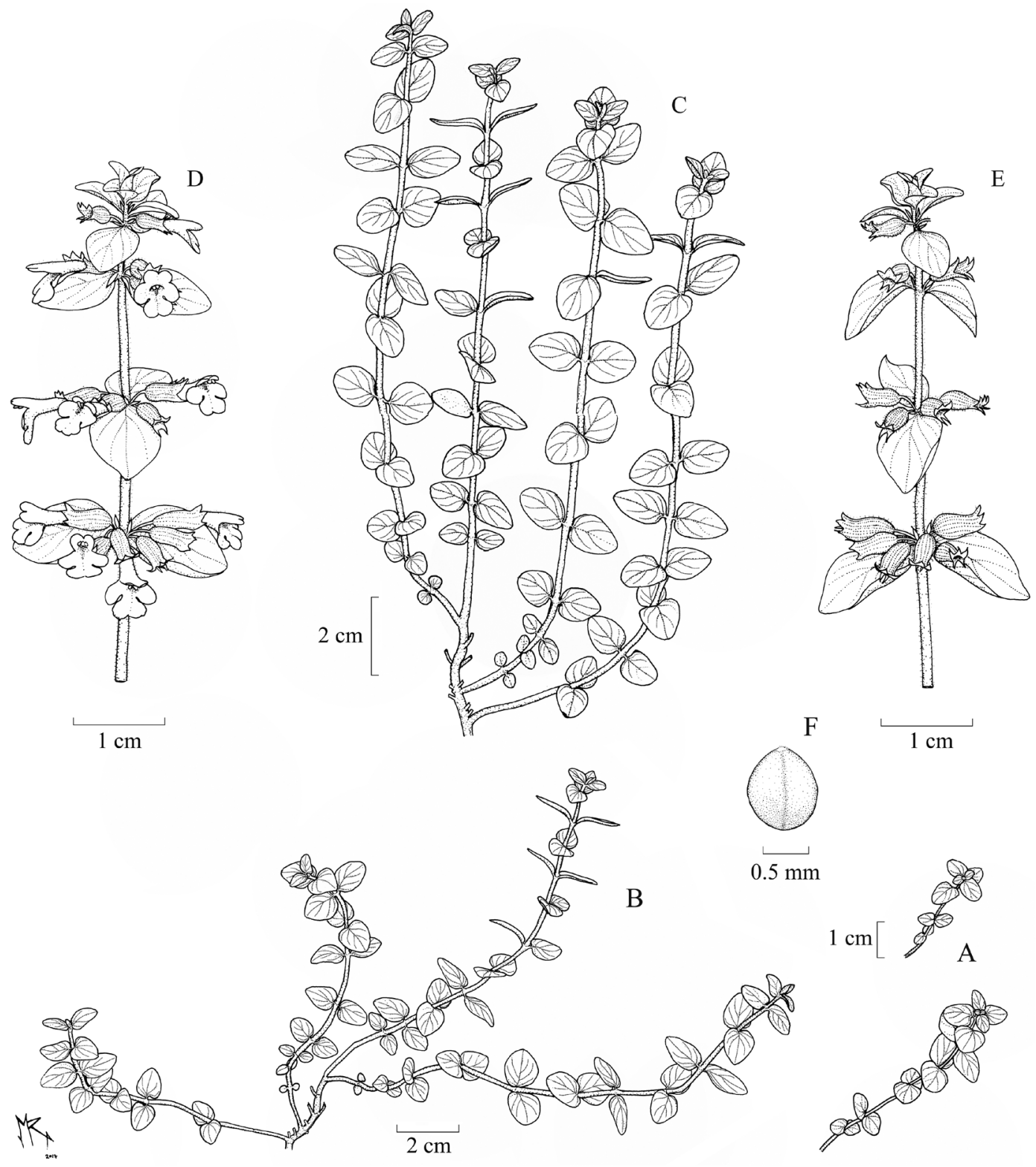

Figure 2: Typical morphology of Hedeoma piperita Benth. in San Francisco Pichátaro, Michoacán, Mexico. Different stages of development: A. seedling a few weeks old; B. juvenile plant with decumbent growth; C. plant in adult stage; D. detail of the inflorescence; E. detail of the infructescence. Drawn by M. Ramírez. 

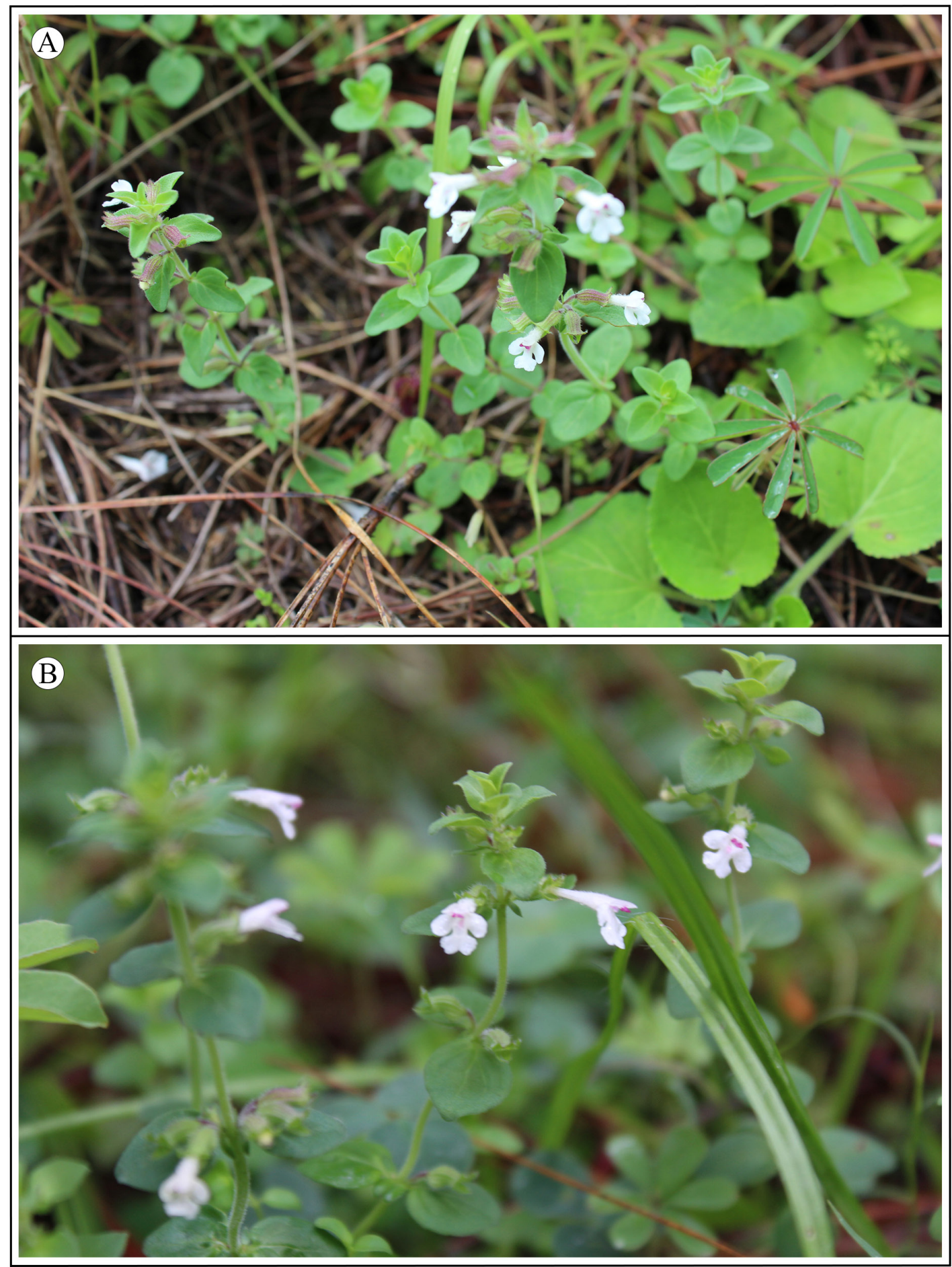

Figure 3: Specimens of Hedeoma piperita Benth. in their natural habitat in the Kananguio valley, Michoacán, Mexico. A. individual of Hedeoma piperita Benth.; B. inflorescence details. Photos: M. L. Herrera-Arroyo.

It grows in hot, warm, semi-dry and temperate climates between 1000 and $2900 \mathrm{~m}$ a.s.l. and is associated with the disturbed vegetation of cloud forest and oak, pine, and juniper woodlands (Pascual, 2016). In general, quiensabe is used to relieve digestive disorders, such as stomach in- flammation, poor digestion and diarrhea, but principally to alleviate stomachache. These uses have been reported in states in central Mexico, including Hidalgo, Michoacán, and Morelos (Caballero and Mapes, 1985; Pascual, 2016; Ceja, 2017). 


\section{Documentation of traditional knowledge}

In order to obtain the traditional knowledge held by the inhabitants of San Francisco Pichátaro concerning the biology (form, life cycle), ecology (distribution zones, habitat, abundance) and management practices of quiensabe (methods and sites of collection, uses and ways of use), as well as its cultural importance, in 2014-2015 we held 75 semi-structured interviews, with community members: 1) 25 with older adults (30-85 years; 12 men, 13 women); 2) 25 with young people (14-20 years; 12 men, 13 women); and 3) 25 with children (8-13 years; 13 men, 12 women). We also established an ongoing dialogue with local people and employed the active-participation technique to forge a closer relationship with the community that facilitated and complemented our understanding of the information generated in the interviews (Hersch Martínez, 1996). We visited some families who use and market the quiensabe, talked with them, participated in the consumption process. We also made 10 field trips in August and September 2014 and 2015, accompanied by six local gatherers (aged 25-70) to document the area of distribution of quiensabe in the locality. To understand more precisely the process of transmission of knowledge, we tested for significant differences between men and women with respect to the knowledge of the plant they possess, as well as known uses of the species (food and medicine) between age groups (children, youth, and adults) using a chi-squared test.

\section{Phenological analysis of quiensabe}

We analyzed 31 plants from five populations established in the Kananguio valley. We selected five to seven individuals per population, recording the height, total number of leaves, branches, flowers, fruits and sprouts for each one every 15 days from March 2014 to March 2015. Monthly averages were plotted to determine the phenological behavior throughout the year and to compare the different stages of phenological development. To achieve this, the average monthly values were standardized and then transformed into percentages, taking the highest value recorded for each variable as $100 \%$. Once these transformations were made, the next step was to graph the data for all the phenological variables.
The phenology of plants is determined by biotic and abiotic factors, among the latter are environmental variables (Ramírez, 2009; Parra-Tabla et al., 2017). We registered temperature, precipitation, relative humidity, dew point, heat index and solar energy through a local meteorology station (UIIM Weather Station, located in Kananguio valley). Monthly averages were calculated for these variables to determine the correlation between the phenological and environmental variables and in this way understand a little more about the ecology of the species. Precipitation and solar radiation had normal distributions, but the other climatic variables were transformed into logarithms because they did not satisfy the normality test. To determine the degree of association between phenological and environmental variables, Spearman's correlation coefficients were calculated. All statistical analyses were conducted with SPSS v. 25.0 statistical Software (IBM, 2017).

\section{Results}

\section{Traditional knowledge}

Our results showed that $60 \%$ of the people interviewed know and have used the quiensabe. Concerning gender, women play a significant role in transmitting this knowledge, as $71 \%$ of the people who stated that they know and use the plant were female $\left(X^{2}=8.02 ; P=0.005\right)$.

Regarding its use as food (tea at breakfast) or medicinal (several sicknesses), there were significant differences in the knowledge that exists among age groups; children and young people used the quiensabe mostly for food purposes ( 75 and $83 \%$, respectively) ( $X^{2}=5 ; P=0.025$ for children and $X^{2}=8 ; P=0.005$ for youth), while adults used mainly for medicinal purposes $(68 \%),\left(X^{2}=4.2 ; P=0.04\right)$. Among the reported medicinal uses, there were for a variety of reasons, such as low blood pressure, stomachache, colic, cough, nervousness, and as aphrodisiac.

Preparing quiensabe tea is a longstanding, traditional practice among residents of San Francisco Pichátaro, who stated that they drink it every morning at breakfast, especially in the rainy season when the plant is more abundant. Also, small branches may be dried in the sun and preserved, so people can have this breakfast tea in other seasons of the year, depending on the amount collected. 
We found that harvesting of quiensabe occurs during the rainy season (June-August). As a result of guided field trips, we could observe that adults know where exactly populations of quiensabe are located, they said to know the sites because this practice is carried out every year; they collect the plant, generally uproot the entire plant, even with roots. Moreover, we observed that adults frequently asked young people to accompany them on these trips, and they talked about the importance of the plant, its uses, and how to find the places where it is located. This is a way of transmitting the knowledge of the plant.

From these field trips, we could also observe that the search for plants can take quite a lot of time, even an entire morning. The size of the plants and their abundance are fundamental factors that determine the amount collected on each visit. Hedeoma piperita populations are currently scarce and consist of few individuals (from 5 to 30). People collect every plant they find, regardless of its size or vegetative state. At the end of the gathering, it was not possible to observe quiensabe plants on the site.

Seventy two percent of the people interviewed recognized that there has not been any appropriate management scheme of this plant. They also point out that the harvest or gathering method generally involves extracting the plants with roots. Additionally, they also recognized that the amounts collected have greatly reduced populations; $56 \%$ of the persons recognized that it is difficult to find populations, and the few that exist have few individuals (most of the time only five or six plants, with a maximum of 30). For these reasons, people must invest quite a lot of time searching for plants to collect sufficient amounts to satisfy the demand of their families and of the local market. One handful (manojito) may contain 30 to 40 plants. The plants gathered are used primarily for domestic consumption and traditional medicine $(90 \%)$ and, to a much lesser degree, for sale (10\%). One family gathers the plant 2-3 times a season, and the number of handfuls harvested depends on how abundant it is at the sites visited.

With respect to the biology and ecology of the species, local people know little about its life cycle, 64\% (of which more than $50 \%$ were adults) indicated that they know it is a perennial plant and that the aerial part dries out in winter, and that it sprouts again in the rainy season. Around $35 \%$ of interviewees (of which $80 \%$ adults and $20 \%$ youth) knew that flowering occurs in the months of July-September, but only $10 \%$ (all of them adults) knew the plant's seeds. No one has ever successfully germinated seeds, and people were totally unaware of aspects related to seed production, dispersal, and germination. The vast majority (85\%) knew the variety with white flowers, but only $15 \%$-all of them adults - knew that the species may also produce purple flowers.

People in Pichátaro recognize six sites where quiensabe populations can be found (Kananguio, Joya Fría, Malpais, Pitaya, La Virgen, Mojonera); however, $80 \%$ of our interviewees collect plants in the Kananguio valley only, because it is the closest site. The other five places are known only by older adults, mainly specialists in traditional medicine. It is important to note that young people and children know the sites and collect plants only in the Kananguio valley. Of these six sites, we visited three throughout the guided field trips, the remaining three were not located due to remoteness and changes in land use.

Our results show that $37 \%$ of interviewees were aware that $H$. piperita is delicate in terms of the environmental conditions it requires, as $71 \%$ mentioned that the sites where populations of quiensabe are found are called parajes (i.e., plains or hillsides that are neither steep nor very rocky, with pasturelands but no agriculture, and free of arboreal vegetation, also known locally as tierras duras (hard lands)).

Given the importance of this species for the community of Pichátaro, some management strategies have been sought, unfortunately without positive results. Several families have tried to "take" plants home to cultivate them in their gardens, either extracting complete plants or planting seeds, but no one has succeeded in this endeavor. Interviewed people said that "it must require conditions that are found only in the hills, because it just does not like being brought into town".

\section{Phenology of Hedeoma piperita}

According to the records obtained, quiensabe showed little development in terms of height during the months 
of March, April, and May 2014, as well as February and March 2015. Nevertheless, in June it reached their greatest height, which was $11.6 \mathrm{~cm}$ on average (only for June). On average, the plant maintained heights above $8 \mathrm{~cm}$ from June to December. It is also important to mention that the height of the plants gradually decreased after December, so in February-March the average height was only approximately $3 \mathrm{~cm}$ (Fig. 4; Table 1).

With respect to the total number of leaves and branches, we found a first peak of foliation and branching in June, and a second one (less than the previous one) in October, immediately after a decrease in both traits

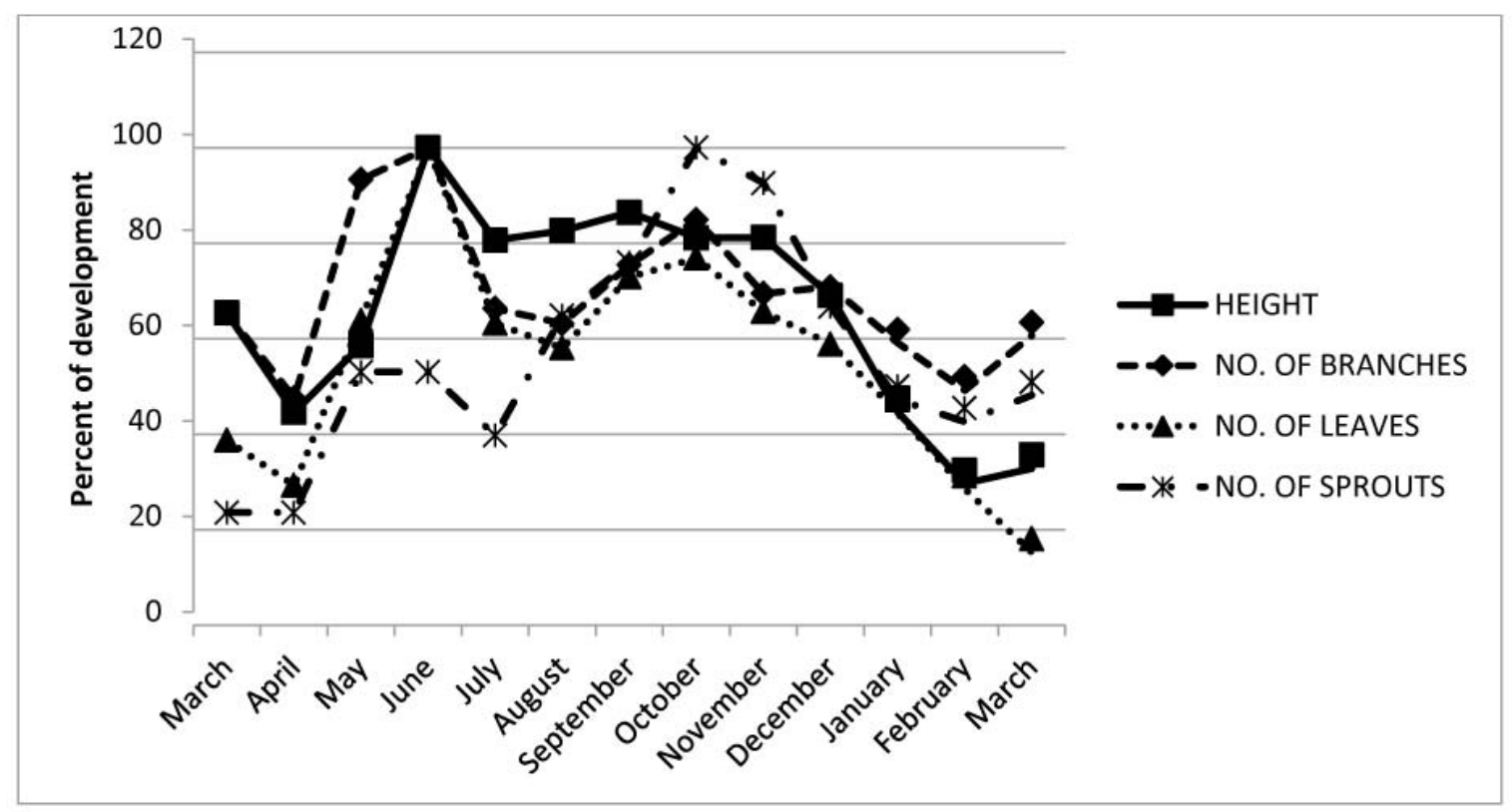

Figure 4: Monthly behavior of vegetative phenological variables in Hedeoma piperita Benth. from March 2014-March 2015 in San Francisco Pichátaro, Michoacán, Mexico.

Table 1: Monthly averages of the phenological variables recorded for Hedeoma piperita Benth. from the Kananguio Valley ( $n=31$ plants), San Francisco Pichátaro, Michoacán, Mexico. Numbers in brackets indicate the standard deviation.

\begin{tabular}{|c|c|c|c|c|c|c|c|c|c|c|c|c|c|}
\hline \multicolumn{11}{|c|}{2014} & \multicolumn{3}{|c|}{2015} \\
\hline Variable & March & April & May & June & July & August & September & October & November & December & January & February & March \\
\hline \multirow[t]{2}{*}{ Height $(\mathrm{cm})$} & 7.60 & 5.18 & 6.80 & 11.63 & 9.37 & 9.60 & 10.05 & 9.43 & 9.43 & 8.02 & 5.20 & 3.45 & 3.81 \\
\hline & $(4.02)$ & $(2.69)$ & $(3.00)$ & (3.06) & $(4.27)$ & (4.67) & (4.95) & $(5.48)$ & (4.95) & $(4.87)$ & (3.78) & (2.67) & $(2.70)$ \\
\hline \multirow{2}{*}{$\begin{array}{l}\text { No. of } \\
\text { branches }\end{array}$} & 13.36 & 9.73 & 19.09 & 20.45 & 13.56 & 12.91 & 15.43 & 17.37 & 14.20 & 14.49 & 12.09 & 10.06 & 12.40 \\
\hline & (7.94) & $(5.33)$ & $(15.64)$ & (15.59) & $(12.16)$ & (12.69) & (14.58) & (15.27) & (12.29) & (12.38) & (13.29) & (11.70) & (11.83) \\
\hline \multirow{2}{*}{$\begin{array}{l}\text { Total no. of } \\
\text { leaves }\end{array}$} & 159.36 & 120.55 & 262.82 & 411.73 & 260.15 & 238.96 & 300.14 & 316.52 & 270.33 & 242.37 & 182.76 & 117.24 & 62.78 \\
\hline & (92.65) & (79.33) & $(264.16)$ & (368.96) & (281.35) & $(317.26)$ & (327.51) & (368.25) & (293.91) & $(261.86)$ & (287.20) & $(220.30)$ & (254.76) \\
\hline \multirow{2}{*}{$\begin{array}{l}\text { No. of } \\
\text { flowers }\end{array}$} & 0 & 0 & 0 & 5.3 & 4.56 & 2 & 2 & 0 & 0 & 0 & 0 & 0 & 0 \\
\hline & 0 & 0 & 0 & (1.1) & (5.06) & (3.92) & (3.92) & 0 & 0 & 0 & 0 & 0 & 0 \\
\hline \multirow[t]{2}{*}{ No. of fruits } & 0 & 0 & 0 & 0 & 0 & 0 & 8.31 & 8.31 & 8.31 & 0 & 0 & 0 & 0 \\
\hline & 0 & 0 & 0 & 0 & 0 & 0 & (11.59) & (11.59) & (11.59) & 0 & 0 & 0 & 0 \\
\hline \multirow{2}{*}{$\begin{array}{l}\text { No. of } \\
\text { sprouts }\end{array}$} & 0.36 & 0.36 & 0.82 & 0.82 & 0.61 & 1 & 1.17 & 1.54 & 1.43 & 1.03 & 0.73 & 0.66 & 0.74 \\
\hline & $(1.21)$ & $(1.21)$ & $(2.71)$ & $(2.71)$ & $(2.02)$ & $(2.26)$ & $(2.81)$ & $(4.60)$ & (3.79) & $(2.46)$ & $(2.01)$ & (1.83) & (1.98) \\
\hline
\end{tabular}


was registered. (Fig. 4; Table 1). Regarding the number of sprouts, we found a somewhat different behavior, during March-April 2014, plants showed very little development with the first peak of development coming in May and June, with a second one (greater than the first one) in October, coinciding with the second peak of foliation and branching (Fig. 4; Table 1).

Flowering occurs from June to September, with the maximum development during June. In July, it began to decrease, and by August-September it had diminished considerably. Almost no flowers were recorded in October, the period when fruits appear. Their development began in September and continued to October and November (Fig. 5; Table 1).

We found significant correlations between some phenological and environmental variables. Temperature and heat index were positive and significantly correlated $(P<0.05)$ with height, number of branches, total number of leaves and number of flowers as well as the dew point $(P<0.01)$. Solar energy was negative and significantly cor-

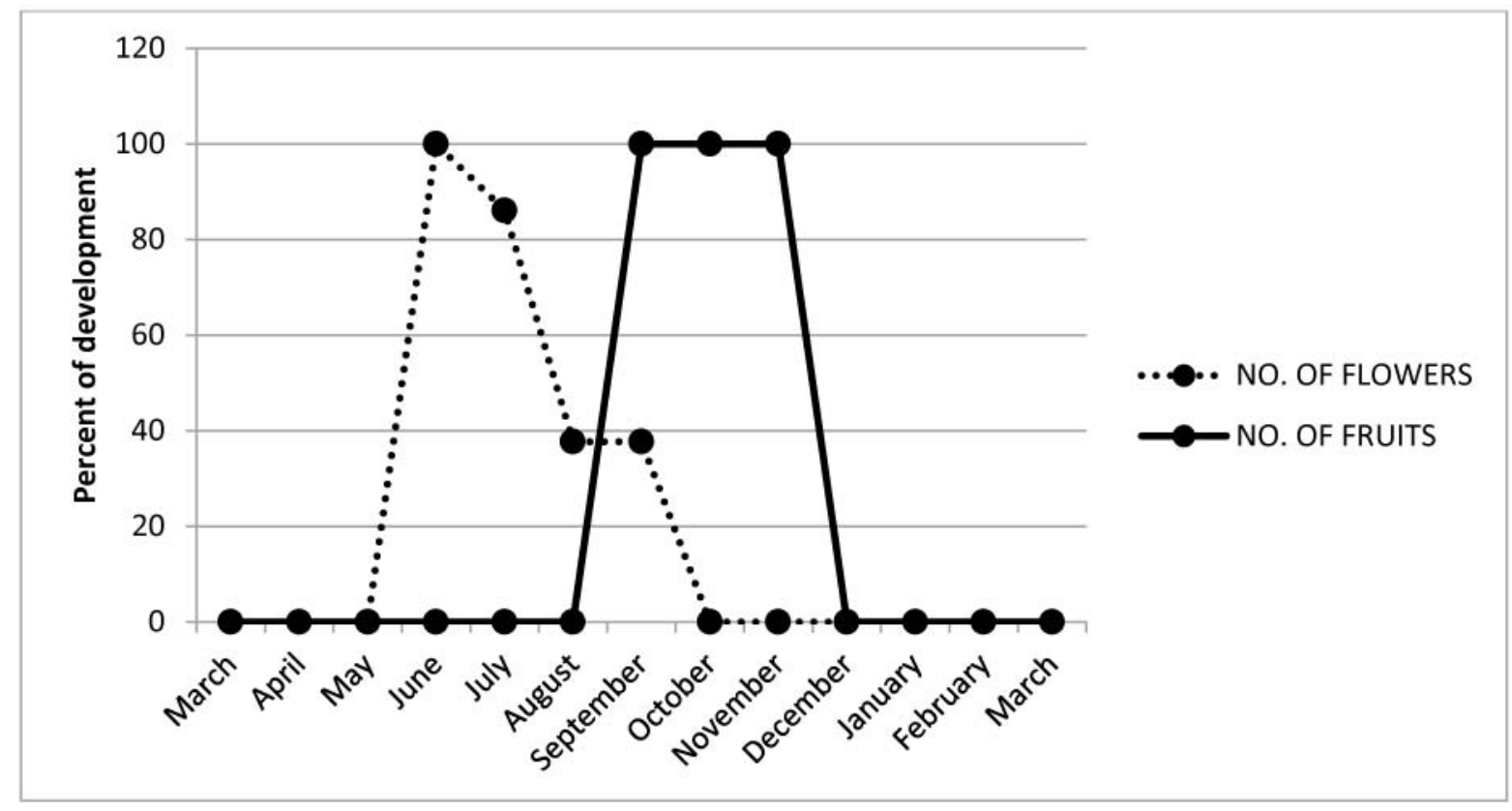

Figure 5: Monthly behavior of reproductive phenological variables in Hedeoma piperita Benth. from March 2014-March 2015 in San Francisco Pichátaro, Michoacán, Mexico.

Table 2: Spearman's correlation coefficients for the climatic and phenological variables of Hedeoma piperita Benth. ( ${ }^{*} \mathrm{P}<0.05$; ${ }^{* *} \mathrm{P}<0.01$; $\mathrm{ns}$ : not significant) in the indigenous community of San Francisco Pichátaro, Michoacán, Mexico.

\begin{tabular}{|c|c|c|c|c|c|c|}
\hline Variable & $\begin{array}{c}\text { Temperature } \\
{ }^{\circ} \mathrm{C}\end{array}$ & $\begin{array}{c}\text { Precipitation } \\
\mathrm{mm}\end{array}$ & $\begin{array}{c}\text { Humidity } \\
\%\end{array}$ & $\begin{array}{c}\text { Dew point } \\
{ }^{\circ} \mathrm{C}\end{array}$ & $\begin{array}{c}\text { Heat index } \\
{ }^{\circ} \mathrm{C}\end{array}$ & $\begin{array}{c}\text { Solar energy } \\
\text { Cal/hr }\end{array}$ \\
\hline Height $(\mathrm{cm})$ & $0.6^{*}$ & $0.34 \mathrm{~ns}$ & $0.52 \mathrm{~ns}$ & $0.65^{* *}$ & $0.62 *$ & $-0.62 *$ \\
\hline No. of branches & $0.54 *$ & $0.45 \mathrm{~ns}$ & $0.52 \mathrm{~ns}$ & $0.66 * *$ & $0.57 *$ & $-0.53 \mathrm{~ns}$ \\
\hline Total no. of leaves & $0.6^{*}$ & $0.3 \mathrm{~ns}$ & $0.6^{*}$ & $0.71 * *$ & $0.63^{*}$ & $-0.61 *$ \\
\hline No. of flowers & $0.61 *$ & $0.55^{*}$ & $0.52 \mathrm{~ns}$ & $0.65^{* *}$ & $0.65 * *$ & $-0.69 * *$ \\
\hline No. of fruits & $0.17 \mathrm{~ns}$ & $0.09 \mathrm{~ns}$ & $0.32 \mathrm{~ns}$ & $0.28 \mathrm{~ns}$ & $0.19 \mathrm{~ns}$ & $-0.08 \mathrm{~ns}$ \\
\hline No. of sprouts & $0.08 \mathrm{~ns}$ & $0.22 \mathrm{~ns}$ & $0.58 *$ & $0.49 \mathrm{~ns}$ & $0.15 \mathrm{~ns}$ & $-0.005 \mathrm{~ns}$ \\
\hline
\end{tabular}


related with height, total number of leaves and number of flowers, while precipitation was positive and significantly correlated with number of flowers (Table 2).

\section{Discussion}

Indigenous knowledge on the management of different species of cultural (Reyes-García et al., 2005, 2006), agricultural (Brush, 1992) and economic interest has been widely documented. Nevertheless, this is one of the first studies that documents traditional knowledge regarding use, biology, and ecology of quiensabe, as well as the phenology of the species. This study is part of a larger project, which aims to contribute to the conservation of wild populations of $H$. piperita (Herrera-Arroyo et al., 2020).

As a non-timber forest resource, quiensabe plays an important role in the lives of the members of the indigenous community of San Francisco Pichátaro as an element of their daily diet and practices of traditional medicine. It has been and is still being used by traditional local healers to treat several ailments, as well as by residents in general, who consume it as part of their diet.

The transmission of this knowledge takes place through oral communication from one generation to the next. It is very likely that, due to their young age, children are precisely in the process of appropriation of knowledge, for this reason, they are still unaware of the different medical uses of quiensabe. As we know, traditional knowledge is dynamic and associated with sociocultural and ecological changes that occur through history. Hence, it is necessary to understand the processes associated with the dynamics of traditional knowledge, in order to maintain and preserve it over time (Berkes et al., 2000; Alencar et al., 2014).

Moreover, like in other cultures (Garro, 1986; Caniago and Siebert, 1998), women are the group with more knowledge about medicinal plants, because they actively participate in this cultural practice, while youth and children are in this process of appropriation of knowledge.

Despite the importance of quiensabe for the Purépecha people, throughout the guided field trips, as well as during the interviews, we observed that current forms of management do not help to ensure the permanence of its populations. Rather, the intensity of gathering, the uprooting of complete plants, and the gathering period that overlaps with the flowering season, could be factors that may accelerate the extinction of this species in the locality. Ghimire et al. (2004) point out that this type of management, non-selective and massive harvesting, threatens the permanence of the resource. Such conditions might determine uncertainty in the availability of the resources but may also enhance people to put in practice some management procedures, to ensure resource availability (González-Insuasti and Caballero, 2007; González-Insuasti et al., 2008). Therefore, implementing actions to conserve this valuable plant is of the highest priority; strategies that are suggested are: not cutting all the individuals of a population, cutting only the aerial part of the plants, carry out selective harvesting for those plants that have already dispersed their seeds, and reproduce the plant through seed or other means of propagation (asexual), that is, a selective harvest at several levels, as pointed out by Ghimire et al. (2004).

Several authors have argued that excessive harvesting of wild plants has significant negative ecological effects for local populations (Cunningham, 2001; Ticktin, 2004; Chediack, 2008), and with consequences from the level of genes and even ecosystems. When the extraction of a resource exceeds its recovery, there is a strong risk that this resource will be lost (Blancas et al., 2010). Other studies suggest that the consequences of the inadequate management of a species are determined mainly by the socioeconomic and political context where they occur (Hiremath, 2004; Ticktin, 2004; Reyes-García et al., 2006; Camou-Guerrero et al., 2007).

As is well-known, the traditional knowledge of plants that indigenous groups succeed in preserving forms a whole set of knowledge of morphological, biological, and ecological aspects (Caballero and Mapes, 1985; Garro, 1986; Benz et al., 2000). This information must be integrated with other types of knowledge; in our case, technical scientific information derived from phenological development of the species as a way to inform management strategies and ensure the permanence of the species in the ecosystems and socio-systems involved.

It is highly likely that this pattern of extraction is reproduced throughout the Purépecha region; another reason why it is urgent to implement actions to foster conservation. The quantitative study of phenology is considered 
key for understanding the functionality of terrestrial ecosystems and consequently for their conservation (Berry and Gorchov, 2004). Our phenological analysis provides valuable information that can be used to improve its management, since our results allow us to better understand the behavior of the plant's phenological variables and their relation to the environment.

Similar to other herbaceous plants in which their greatest development occurs during the rainy season (Joshi and Janarthanam, 2004), H. piperita produced a larger biomass in the rainy season, which coincides with the extraction period. The flowering season also occurred in the months of June-August, thus also coinciding with the gathering period. This pattern of collecting the species during its reproductive stage disturbs the process of sexual reproduction, while the inadequate uprooting of complete plants prevents asexual reproduction. Because populations cannot recover under these conditions, there is a real danger that quiensabe could become extinct in Pichátaro. Documentation of the environmental conditions necessary for the development of the species can contribute to the formulation of management strategies for wild and cultivated populations, which allow increasing their availability.

With respect to other findings, the guided field trips allowed us to observe that this species shows an aggregate pattern of spatial distribution. Their populations were situated in pine forests, on partially sunny slopes, protected by pine trees, and shrubs of the genus Baccharis L. (Asteraceae). Vegetative phenology was highly related with environmental traits. Environmental variables, such as temperature, humidity, dew point, and heat index were fundamental for the development of the plant; its growth and development was carried out optimally when the environmental conditions were warmer and with higher humidity. Likewise, they developed better with lower amount of solar energy received, which is why their populations are almost always associated with pine forests, on semi-open slopes, under the protection of trees and shrubs. One important aspect of this aggregate spatial distribution of populations is that they are limited to very small geographic areas, some of them measuring less than $4 \mathrm{~m}^{2}$. We also found that very few populations remain and that some of these had very few individuals. The consequences of the combination of all these aspects (those related to species management and the biology and ecology of quiensabe) is that populations of this valuable resource have decreased significantly.

Quiensabe ( $H$. piperita) is a wild species with high use value in the indigenous community of San Francisco Pichátaro, mainly as an infusion for preparing tea and as a natural remedy in the traditional medicine. However, quiensabe is actually in danger of local extirpation in this area, since current reports indicate a severe scarcity in the number of populations and plants (Herrera-Arroyo et al., 2020). Therefore, urgent action is required to prevent the disappearance of quiensabe from sites around San Francisco Pichátaro. The information gathered on the use, phenology and phenological relations with environmental variables in the present study contributes with important knowledge that can be used to design sustainable conservation strategies. Future biological studies must carry out experiments of seed germination and plant propagation, which will make it feasible to conserve the species ex situ by local communities.

Other studies on edible plants carried out in the region (Santos, 2013; Rodríguez, 2016; Contreras, 2018) and useful plants (Santos, 2014) revealed that many of the investigated species have a great potential for use, while others require different management strategies for their conservation, due to their limited availability, as well as erosion in the transmission of traditional knowledge regarding their use. Such strategies can be directed to the species, such as cultivation, selective collection, tolerance, or habitat conservation. These studies make it possible to identify the species on which there is greater human pressure and those that, according to their scarcity, and their restricted distribution, are at greater risk of becoming extinct as a result of their use.

\section{Author contributions}

MLHA designed the study, conducted field trips, performed statistical analysis and wrote the manuscript, MPC applied the interviews, conducted field trips, took the phenological data systematized the information, and performed statistical analysis, YR reviewed the statistical analysis and critically reviewed the manuscript. 


\section{Funding}

The present study was carried out with private funds from the authors.

\section{Acknowledgements}

We thank the community of San Francisco Pichátaro for allowing us to enter into their worldview through the study of quiensabe, M. Álvarez-Jara for the elaboration of the map, and Luis Rey Flores Pérez for figure elaboration.

\section{Literature cited}

Alarcón-Chaires, P. 2009. Etnoecología de los Indígenas P'hurépecha: Una guía para el análisis de la apropiación de la naturaleza. Centro de Investigaciones en Ecosistemas, Universidad Nacional Autónoma de México. Morelia, México. 122 pp.

Alencar, N. L., W. S. F. Junior and U. P. Albuquerque. 2014. Medicinal plant knowledge richness and sharing in Northeastern Brazil. Economic Botany 68: 371-382. DOI: https://doi.org/10.1007/s12231-014-9284-5

Argueta, A. 2008. Los saberes P'urhépecha, los animales y el diálogo con la naturaleza. Universidad Nacional Autónoma de México, Universidad Michoacana de San Nicolás de Hidalgo, Universidad Intercultural Indígena de Michoacán, Programa de Naciones Unidas para el Medio Ambiente. México, D.F., México. 241 pp.

Barrera-Bassols, N. and A. Zinck. 2003. Land moves and behaves: indigenous discourse of sustainable land management in Pichataro, Patzcuaro basin, Mexico. Geograsfika Annaler: Series A, Physical Geography 85(3-4): 229-245. DOI: https:// doi.org/10.1111/j.0435-3676.2003.00202.x

Barrera-Bassols, N. and V. M. Toledo. 2005. Ethnoecology of the Yucatec Maya: symbolism, knowledge and management of natural resources. Journal of Latin American Geography 4(1): 9-41. DOI: https://doi.org/10.1353/lag.2005.0021

Beltrán-Rodríguez, L. A., B. Martínez-Rivera and A. P. Maya. 2012. Etnoecología de la Flor de Catarina -Laelia autumnalis (La Llave \& Lex.) Lindl.- (Orchidaceae) en una comunidad campesina al sur del estado de Morelos, México: Conservando un recurso y preservando saberes populares. Etnobiología 10(1): 1-17.

Bentham, G. 1832-1836. Labiatarum genera et species. Ed. George Bentham. Ridgeway, London. 783 pp.
Benz, B. F., J. Cevallos, F. Santana, J. Rosales and M. Graf. 2000. Losing knowledge about plant use in the Sierra de Manantlan Biosphere Reserve, Mexico. Economic Botany 54: 183-191. DOI: https://doi.org/10.1007/BF02907821

Berkes, F., J. Colding and C. Folke. 2000. Rediscovery of traditional ecological knowledge as adaptive management. Ecological Applications 10(5): 1251-1262. DOI: https://doi. org/10.2307/2641280

Berry, E. and D. Gorchov. 2004. Reproductive biology of the dioecious understorey palm Chamaedora radicalis in Mexican cloud forest: pollination vector, flowering phenology and female fecundity. Journal of Tropical Ecology 20(4): 369-376. DOI: https://doi.org/10.1017/ S0266467404001397

Blancas, J., A. Casas, S. Rangel-Landa, A. Moreno-Calles, I. Torres, E. Pérez-Negrón, L. Solís, A. Delgado-Lemus, F. Parra, Y. Arellanes, J. Caballero, L. Cortés, R. Lira and P. Dávila. 2010. Plant management in the Tehuacán-Cuicatlán Valley, Mexico. Economic Botany 64(4): 287-302. DOI: https://doi. org/10.1007/s12231-010-9133-0

Blancas, J., A. Casas, D. Pérez-Salicrup, J. Caballero and E. Vega. 2013. Ecological and socio-cultural factors influencing plant management in Náhuatl communities of the Tehuacán Valley, Mexico. Journal of Ethnobiology and Ethnomedicine 9: 39. DOI: https://doi.org/10.1186/1746-4269-9-39

Blancas, V. J., A. Casas, A. I. Moreno-Calles and J. Caballero. 2016. Cultural motives of plant management and domestication. In: Lira, R., A. Casas and J. Blancas (eds.). Ethnobotany of Mexico, Ethnobiology book series (EBL). Springer. New York, USA. pp. 233-255 DOI: https://doi.org/10.1007/9781-4614-6669-7_10

Bocco, G., A. Velázquez and A. Torres. 2000. Ciencia, comunidades indígenas y manejo de recursos naturales. Un caso de investigación participativa en México. Interciencia 25: 64-70.

Boege, S. E. 2008. El patrimonio biocultural de los pueblos indígenas de México. Instituto Nacional de Antropología e Historia, Comisión Nacional para el Desarrollo de los Pueblos Indígenas. México, D.F., México. 342 pp.

Browning, D. M., T. M. Crimmins, D. K. James, S. Spiegal, M. R. Levi, J. P. Anderson and D. P. C. Peters. 2018. Synchronous species responses reveal phenological guilds: implications for management. Ecosphere 9(9): e02395. DOI: https://doi. org/10.1002/ecs2.2395 
Brush, S. B. 1992. Ethnoecology, Biodiversity, and Modernization in Andean Potato Agriculture. Journal of Ethnobiology 12(2): 161-185.

Caballero, J. 1982. Notas sobre el uso de los recursos naturales entre los antiguos Purépecha. Biótica 7: 41-42.

Caballero, N. J. and S. C. Mapes. 1985. Gathering and subsistence patterns among the P'urepecha Indians of México. Journal of Ethnobiology 5(1): 31-47.

Camou-Guerrero, A., V. Reyes-García, M. Martínez-Ramos and A. Casas. 2007. Knowledge and use value of plant species in a Rarámuri community: a gender perspective for conservation. Human Ecology 36: 259-272. DOI: https://doi. org/10.1007/s10745-007-9152-3

Caniago, I. and F. S. Siebert. 1998. Medicinal plant ecology, knowledge and conservation in Kalimantan, Indonesia. Economic Botany 52: 229-250. DOI: https//doi.org/10.1007/ BF02862141

Casas, A., S. Rangel-Landa, I. Torres, E. Pérez-Negrón, F. Parra, A. Delgado, J. Blancas, B. Farfán and I. Moreno. 2009. In situ management and conservation of plant resources in the Tehuacán-Cuicatlán Valley, México: An Ethnobotanical and Ecological approach. In: Albuquerque, U. P. and M. AlvesRamos (eds.). Current Topics in Ethnobotany. Research Signpost. Kerala, India. 1-25 pp.

Casas, A., R. Lira, I. Torres, A. Delgado, A. I. Moreno-Calles, S. Rangel-Landa, J. Blancas, C. Larios, L. Solís, E. Pérez-Negrón, M. Vallejo, F. Parra, B. Farfán-Heredia, Y. Arellanes and N. Campos. 2016. Ethnobotany for Sustainable Ecosystem Management: A regional perspective in the Tehuacán Valley. In: Lira, R., A. Casas and J. Blancas (eds.). Ethnobotany of Mexico, Ethnobiology book series (EBL) Springer. New York, USA. Pp. 179-206. DOI: https//doi.org/10.1007/978-14614-6669-7_8

Ceja, H. S. 2017. Aspectos ecológicos y germinación in vitro de Hedeoma piperita Benth. para su aprovechamiento sustentable en Cherán, Michoacán, México. Tesis de licenciatura, Universidad Intercultural Indígena de Michoacán. Tingambato, México. 66 pp.

Challenger, A. 1998. Utilización y conservación de los ecosistemas terrestres de México, pasado, presente y futuro. Comisión Nacional para el Conocimiento y Uso de la Biodiversidad, Universidad Nacional Autónoma de México and Agrupación Sierra Madre S.C. México, D.F., México. 847 pp.
Chediack, S. E. 2008. The effect of forest exploitation on structure, diversity, and floristic composition of Palmito-dominated Atlantic Forests at Misiones, Argentina. Revista de Biología Tropical 56: 721-738.

Contreras, B. I. V. 2018. Etnobotánica de Xakua en sistemas agrícolas tradicionales de San Francisco Pichátaro, Tingambato, Michoacán, México. Tesis de licenciatura, Universidad Michoacana de San Nicolás de Hidalgo. Tingambato, México. 172 pp.

Cunningham, A. 2001. Applied ethnobotany: people, wild plant, use and conservation. Earthscan Publications. London, UK. 320 pp.

Enquist, C. A. F., J. L. Kellermann, K. L. Gerst and A. J. MillerRushing. 2014. Phenology research for natural resource management in the United States. International Journal of Biometeorology 58: 579-589. DOI: https://doi.org/10.1007/ s00484-013-0772-6

Felipe, Q. J. L. 2015. Valoración comunitaria de los recursos forestales no maderables (RFNM) en la Comunidad de San Francisco Pichátaro, Michoacán. Tesis de licenciatura, Universidad Intercultural Indígena de Michoacán. Tingambato, México. 75 pp.

Fenner, M. 1998. The phenology of growth and reproduction in plants. Perspectives in Plant Ecology, Evolution and Systematics 1(1): 78-91. DOI: https://doi.org/10.1078/14338319-00053

Fiallo, F, V., M. M. Granda, H. C. M. Lemes and F. C. A. Rodríguez. 2000. Estudios fenológicos en plantas medicinales XI. Revista Cubana de Plantas Medicinales 5: 106-113.

Garro, L. 1986. Intracultural variation in folk medicinal knowledge: A comparison between curers and noncurers. American Anthropologist 88(2): 351-370. DOI: https//doi. org/10.1525/aa.1986.88.2.02a00040

Ghimire, S., D. McKey and Y. Aumeeruddy-Thomas. 2004. Heterogeneity in ethnoecological knowledge and management of medicinal plants in the Himalayas of Nepal: implications for conservation. Ecology and Society 9(3): 6. DOI: https//doi.org/10.5751/ES-00708-090306

González-Insuasti, M. S. and J. Caballero. 2007. Managing Plant Resources: How intensive can it be? Human Ecology 35: 303-314. DOI: https//doi.org/10.1007/s10745-006-90638

González-Insuasti, M. S., C. Martorell and J. Caballero. 2008. Factors that influence the intensity of non-agricultural 
management of plant resources. Agroforestry Systems 74: 1-15. DOI: https://doi.org/10.1007/s10457-008-9148-z

Herrera-Arroyo, M. L., Y. Rico and B. Y. Bedolla-García. 2020. Morphotype divergence and genetic diversity of Hedeoma piperita Benth. in western Mexico. Molecular Biology Reports 47(11): 8925-8934. DOI: https://doi.org/10.1007/ s11033-020-05946-x

Hersch Martinez, P. 1996. Destino común: los recolectores y su flora medicinal: el comercio de flora medicinal silvestre desde el Suroccidente Poblano (Serie Antropología). Instituto Nacional de Antropología e Historia. México, D.F., México. 262 pp.

Hiremath, A. J. 2004. The ecological consequences of managing forests for non-timber products. Conservation and Society 2(2): 211-216.

IBM. 2017. IBM SPSS Statistics for Windows, Version 25.0. IBM Corp. Armonk, USA.

Irving, R. S. 1980. The systematics of Hedeoma (Labiatae). Sida 8: 218-295.

Joshi, V. C. and M. K. Janarthanam. 2004. The diversity of lifeform type, habitat preference and phenology of the endemics in the Goa region of the Western Ghats, India. Journal of Biogeography 31(8): 1227-1237. DOI: https://doi. org/10.1111/j.1365-2699.2004.01067.x

Laird, S. 2002. Biodiversity and Traditional Knowledge: Equitable Partnerships in Practice. Earthscan. London, UK. 545 pp.

Lara-Cabrera, S. I., B. Y. Bedolla-García, S. Zamudio and G. Domínguez-Vázquez. 2016. Diversidad de Lamiaceae en el Estado de Michoacán, México. Acta Botanica Mexicana 116: 107-149. DOI: https://doi.org/10.21829/ abm116.2016.1120

Lira, R., A. Casas, R. Rosas-López, M. Paredes-Flores, E. PérezNegrón, S. Rangel-Landa, L. Solís, I. Torres and P. Dávila. 2009. Traditional knowledge and useful plant richness in the Tehuacán-Cuicatlán Valley, Mexico. Economic Botany 63: 271-287. DOI: https://doi.org/10.1007/s12231-0099075-6

López-Hoffman, L. E., I. E. Monroe, E. Narváez, M. MartínezRamos and D. D. Ackerly. 2006. Sustainability of mangrove harvesting: how do harvester's perceptions differ from ecological analysis? Ecological Society 11(2): 14. DOI: https://doi.org/10.5751/ES-01820-110214
Martínez-Gordillo, M., I. Fragoso-Martínez, M. R. García-Peña and O. Montiel. 2013. Géneros de Lamiaceae de México, diversidad y endemismo. Revista Mexicana de Biodiversidad 84(1): 30-86. DOI: https://doi.org/10.7550/rmb.30158

Martínez-Gordillo, M., B. Bedolla-García, G. Cornejo-Tenorio, I. Fragoso-Martínez, M. R. García-Peña, J. G. GonzálezGallegos, S. I. Lara-Cabrera and S. Zamudio. 2017. Lamiaceae de México. Botanical Sciences 95(4): 780-806. DOI: https:// doi.org/10.17129/botsci.1871

Parra-Tabla, V., L. Abdala-Roberts, P. Tellez, N. Celaya, L. SalinasPeba and C. Alonso. 2017. Fenología de floración y visitantes florales en especies herbáceas. In: Ramos-Zapata, J., V. Parra-Tabla, J. Leirana-Alcocer, A. González-Moreno and X. Chiappa-Carrara (eds.). Ecología funcional de la Reserva de la Biósfera Ría Lagartos. Secretaría de Investigación y Educación Superior, Universidad Autónoma de Yucatán, Universidad Nacional Autónoma de México. Mérida, México. 105-121 pp.

Pascual, C. M. M. 2016. Fenología y propagación en huerto de la planta Quiensabe (Hedeoma piperita Benth.) en la comunidad de San Francisco Pichátaro Michoacán. Tesis de licenciatura, Universidad Intercultural Indígena de Michoacán. Tingambato, México. 72 pp.

Pérez-Negrón, E. and A. Casas. 2007. Use, extraction rates and spatial availability of plant resources in the TehuacánCuicatlán Valley, Mexico: The case of Santiago Quiotepec, Oaxaca. Journal of Arid Environments 70(2): 356-379. DOI: https://doi.org/10.1016/j.jaridenv.2006.12.016

PROCYMAF II. 2004. Evaluación rural participativa de la comunidad indígena San Francisco Pichátaro, Tingambato, Mich. Investigaciones Aplicadas en Ciencias Ambientales y Sociales (IACATAS, A.C.).-Proyecto de Conservación y Manejo Sustentable de Recursos Forestales en México. PROCYMAF II. Pátzcuaro, México. 140 pp.

Ramírez, N. 2009. Correlaciones entre la fenología reproductiva de la vegetación y variables climáticas en los altos Llanos Centrales Venezolanos. Acta Botánica Venezolana 32: 333-362.

Reyes-García, V., V. Vadez, T. Huanca, W. Leonard and D. Wilkie. 2005. Knowledge and consumption of wild plants: A comparative study in two Tsimane' villages in the Bolivian Amazon. Ethnobotany Research and Applications 3: 201207. DOI: https//doi.org/10.17348/era.3.0.201-208 
Reyes-García, V., T. Huanca, V. Vadez, W. Leonard and W. Wilkie. 2006. Cultural, practical and economic value of wild plants: a quantitative study in the Bolivian Amazon. Economic Botany 60: 62-74. DOI: https://doi.org/10.1663/00130001(2006)60[62:CPAEVO]2.0.CO;2

Reyes-García, V. and S. Martín. 2007. Etnoecología: punto de encuentro entre naturaleza y cultura. Ecosistemas 16: 4655.

Rodríguez, M. L. 2016. Conocimiento, disponibilidad y manejo de plantas comestibles de recolección en San Francisco Pichátaro, Michoacán, México. Tesis de maestría, Universidad Autónoma Chapingo. Morelia, México. 143 pp.

Santos, R. M. L. 2013. Aspectos ecológicos y difusión del conocimiento de quelites de San Juan Carapan, Michoacán: bases para su aprovechamiento sustentable. Tesis de licenciatura, Universidad Intercultural Indígena de Michoacán. Tingambato, México 130 pp.

Santos, E. M. L. 2014. Etnoecología etnobotánica y aspectos ecológicos de plantas útiles de la comunidad P'urhepecha San Juan Carapan. Tesis de licenciatura, Universidad Intercultural Indígena de Michoacán. Tingambato, Michoacán, México. 66 pp.

Shiva, V. 2008. Los monocultivos de la mente. Ed. FINEO. México, D.F., México 235 pp.

Suarez, C., E. Espinosa and M. Álvarez. 2000. Monografía de Pichátaro. Centro de Cooperación Regional para la Educación de Adultos en América Latina (CREFAL). Pátzcuaro, México. 125 pp.
Terborgh, J. 1992. Diversity and the tropical rain forest. Scientific American Library. New York, USA. 242 pp.

Ticktin, T. 2004. The ecological implications of harvesting non-timber forest products. Journal of Applied Ecology 41(1): 11-21. DOI: https://doi.org/10.1111/j.13652664.2004.00859.x

Toledo, V. M. 1992. What is ethnoecology?: Origins, scope and implications of rising discipline. Etnoecológica 1: 5-21.

Toledo, V. M. 2002. Ethnoecology: a conceptual framework for the study of indigenous knowledge e of nature. In: Stepp, J. R., F. S. Wyndham and R. K. Zarger (eds.). Ethnobiology and biocultural diversity: Proceedings of the 7th International Congress of Ethnobiology. Athens, Georgia, USA, October 2000. Athens, USA. 511-522 pp.

Toledo, V., P. Alarcón-Chaires, P. Moguel, M. Olivo, A. Cabrera, E. Leyequien and A. Rodríguez-Aldabe. 2002. Biodiversidad y pueblos indios en México y Centroamérica. Biodiversitas 43: $1-8$.

Toledo, V. M. and N. Barrera-Bassols. 2008. La memoria biocultural. La importancia ecológica de las sabidurías tradicionales. Icaria Editorial. Barcelona, España. 233 pp. 